\title{
IMPLEMENTASI PROGRAM E-GOVERNMENT KECAMATAN BATAM KOTA
}

\section{TAHUN 2018}

\author{
Gerry Armando', Muhammad Solihin², dan Diah Ayu Pratiwi \\ ${ }^{1}$ Program Studi Ilmu Pemerintahan, Fakultas Ilmu Sosial dan Ilmu Politik, Universitas Riau Kepulauan \\ Indonesia \\ gerrynoah021@gmail.com \\ ${ }^{2}$ Program Studi Ilmu Pemerintahan, Fakultas Ilmu Sosial dan Ilmu Politik, Universitas Riau Kepulauan \\ sm10rome@gmail.com \\ ${ }^{3}$ Program Studi Ilmu Pemerintahan, Fakultas Ilmu Sosial dan Ilmu Politik, Universitas Riau Kepulauan \\ diah_mahdan@yahoo.co.id
}

\begin{abstract}
Abstrak
E-government merupakan teknologi informasi dan komunikasi agar mempermudah masyarakat dalam mengakses informasi Pemerintahan. Kecamatan Batam Kota memiliki website yang kurang aktif dalam melayani dan berbagi informasi kepada masyarakat. Tujuan penelitian ini untuk mengetahui dan menganalisis faktor pendukung dan penghambat program website Kecamatan Batam Kota. Metode penelitian menggunakan pendekatan kualitatif dengan analisa deskriptif. Pengumpulan data melalui studi lapangan berupa observasi, wawancara dan dokumentasi. Informan penelitian ditentukan secara purposive sampling. Hasil penelitian ini menunjukkan bahwa kebijakan mengenai egovernment di Kota Batam sudah ada namun dalam implementasinya, website Kecamatan Batam Kota belum berjalan efektif dalam melayani masyarakat. Pelayanan yang di harapkan lebih cepat berbasis website belum dapat terwujud. Ini seharusnya di perhatikan agar website Kecamatan Batam Kota bisa lebih baik.

Kata Kunci: implementasi kebijakan, e-government, website pemerintah, kecamatan Batam Kota
\end{abstract}

\begin{abstract}
Abstact
E-government is information and communication technology in order to facilitate the public in accessing Government information. Batam City District has awebsite that is less active in serving and sharing information to the public. The purpose of this study was to determine and analyze the supporting and inhibiting factors of the Batam City District website program. The research method uses a qualitative approach with descriptive analysis. Data collection through field studies in the form of observation, interviews and documentation. Research informants were determind by purposive sampling. The resultsof this study indicate that the policy regarding e-government in Batam City already exists but in its implementation, the Batam City District website has not been effective in serving the community. The service that is expected to be faster based on the website has not yet been realized. This should be noted so that the Batam City District website can be better.

Keywords: Policy Implementation, E-Government, Government Website, Batam Kota District.
\end{abstract}




\section{PENDAHULUAN}

Di era globalisasi seperti sekarang ini yang telah membuat kehidupan masyarakat lebih simple dan lebih mudah adalah teknologi informasi dan komunikasi. Dengan adanya kemudahan-kemudahan yang diberikan oleh teknologi tersebut, mendorong semua masyarakat untuk memanfaatkan teknologi informasi dan komunikasi yang berguna membantu dalam menjalani setiap aktifitas sehari-harinya. Tuntutan-tuntutan aktifitas masyarakat yang semakin meningkat dan juga padat menyebabkan informasi sangat dibutuhkan dan diperlukan, sehingga perlu media penyebaran yang bisa diakses untuk semua orang. Berdasarkan dari Undang-Undang Republik Indonesia No. 14 Tahun 2008 tentang keterbukaan informasi publik sebagai salah satu payung hukum di Indonesia yang dikeluarkan demi memberikan kewajiban kepada setiap-setiap badan publik ataupun suatu instansi pemerintahan untuk membuka suatu akses bagi masyarakat dalam mendapatkan informasi publik kecuali beberapa informasi tertentu. Kemudian juga, dikeluarkannya INPRES No. 3 Tahun 2003 tentang Kebijakan dan Strategi Nasional pengembangan $e$ government sebagai upaya lanjutan suatu proses untuk mendukung penerapan e-government dalam rangka meningkatkan serta memaksimalkan suatu kualitas pelayanan kepada masyarakat khususnya pelayanan informasi pemerintahan agar terciptanya Good governance.

Pemerintah Provinsi Kepulauan Riau juga memiliki peraturan ataupun kebijakan mengenai e-government sebagai berikut Menurut Peraturan Gubernur Kepulauan Riau Nomor 50 Tahun 2017 tentang pelaksanaan dan pengembangan e-government di Kepulauan Riau. Pemerintah Kota Batam melalui Peraturan Walikota Batam No.06A Tahun 2006 Tentang Pengembangan e-government di Lingkungan Pemerintah Kota Batam juga mempertegas lagi perlunya pengembangan Teknologi Informasi di lingkungan Pemerintah Kota Batam karna Perkembangan dunia teknologi informasi dan komunikasi yang cepat akan memberikan dampak yang luar biasa dalam pola kehidupan masyarakat Kota Batam. Menurut Kumorotomo (2008: 1) Komitmen pimpinan organisasi dan lemahnya sumberdaya manusia, misalnya, merupakan dua faktor penting yang sering menjadi kendala pengembangan $e$ government.

Website resmi Kecamatan Batam Kota dimana masih jauh dari harapan peraturanperaturan yang sudah di tetapkan. Kecamatan sebagai suatu instansi pelayanan publik di tuntut agar memperbaiki dan juga senantiasa melakukan reformasi serta juga harus 
mengantisipasi perkembangan-perkembangan masyarakat milenial yang terjadi apalagi di era digital yang serba mudah seperti pada saat ini. Dalam hal ini website pemerintah sangat berperan sekali dan juga sudah menjadi suatu bagian yang sangat penting dari suatu instansi khususnya Kecamatan. Namun, di dalam perkembangannya e-government masih jauh dari harapan masyarakat khususnya masyarakat di lingkungan Kecamatan Batam Kota. Masih banyak yang belum mampu menganggap bahwa e-government sebagai suatu prioritas ataupun sebuah kebutuhan informasi bagi masyarakat. e-government hanya di pandang sebagai proyek yang hanya harus diikuti dan menjadi sebuah trend ataupun hanya sekedar ada saja di kalangan pemerintah padahal jika website tersebut di kontrol dengan baik dan benar maka berdampak sedemikian besar untuk masyarakat ataupun pengguna informasinya.

Jadi pada dasarnya yang harus dapat kita tekankan bahwa e-government merupakan suatu program pemerintah yang harus di jalankan dengan baik dan benar bukan hanya sekedar mengikuti saja apalagi hanya sekedar ada saja namun juga harus dapat di implementasikan dengan bersungguh-sungguh sehingga dapat menciptakan sebuah pelayanan yang baik bagi Kecamatan Batam Kota yang akan berkelanjutan di masa yang akan datang. Oleh karena itu dengan pemanfaatan teknologi informasi dan komunikasi tersebut tentunya sangat diharapkan sekali dapat membantu dan memudahkan masyarakat khususnya daerah lingkungan Kecamatan Batam Kota sebagai salah satu Kecamatan yang berada di tengahtengah Kota Batam untuk mendapatkan informasi yang praktis tanpa harus mengunjungi Kecamatannya terlebih dahulu untuk mengetahui informasi yang dicari ataupun yang dibutuhkan. Untuk mengetahui lebih lanjut perkembangan website yang di lakukan setiap Kecamatan yang ada di Kota Batam berikut ini adalah 12 Kecamatan yang ada di Kota Batam sebagai berikut:

Tabel 1 Data Website Kecamatan Kota Batam

\begin{tabular}{|c|l|l|l|}
\hline No & \multicolumn{1}{|c|}{ Kecamatan } & \multicolumn{1}{|c|}{ Website Kecamatan } & Postingan Terakhir \\
\hline 1. & Batam Kota & www.kecbatamkota.batam.co.id & 9 Maret 2017 \\
\hline 2. & Batu Aji & www.kecbatuaji.batam.go.id & 27 Agustus 2018 \\
\hline 3. & Batu Ampar & www.kecbatuampar.batam.go.id & 28 November 2018 \\
\hline 4. & Belakang Padang & www.kecbelpadang.batam.go.id & 2 Maret 2018 \\
\hline 5. & Bengkong & www.kecbengkong.batam.go.id & 7 Januari 2019 \\
\hline 6. & Bulang & www.kecbulang.batam.go.id & 8 Maret 2018 \\
\hline 7. & Galang & www.kecgalang.batam.go.id & 8 Maret 2018 \\
\hline 8. & Lubuk Baja & www.keclubukbaja.batam.go.id & 2 Maret 2018 \\
\hline
\end{tabular}




\begin{tabular}{|c|l|l|l|}
\hline 9. & Nongsa & www.kenongsa.batam.go.id & 8 Maret 2018 \\
\hline 10. & Sagulung & www.kecsagulung.batam.go.id & 8 Maret 2018 \\
\hline 11. & Sekupang & www.kecsekupang.batam.go.id & 1 Maret 2018 \\
\hline 12. & Sungai Beduk & www.kecsungaibeduk.batam.go.id & 27 Oktober 2017 \\
\hline
\end{tabular}

Sumber : www.batam.go.id, 2018

Dapat dilihat bahwa website Kecamatan Batam Kota paling lama terakhir update dari ke-12 Kecamatan yang ada di Kota Batam. Website tersebut merupakan website kedua dari website yang di kembangkan oleh Dinas Komunikasi dan informasi Kota Batam. Berikut merupakan data perbandingan website Kecamatan Batam Kota yang ada di Kota Batam melalui 2 website yang berbeda sebagai berikut:

Tabel 2 Data Perbandingan Website Kecamatan Batam Kota

\begin{tabular}{|c|c|c|}
\hline Website & Tahun & Kategori \\
\hline \multirow{2}{*}{ www.kecbatamkota.batam.go.id } & 2019 & Kurang aktif \\
\cline { 2 - 3 } & 2018 & Kurang aktif \\
\cline { 2 - 3 } & 2017 & Kurang aktif \\
\hline \multirow{2}{*}{ www.skpd.batamkota.go.id } & 2016 & Kurang aktif \\
\cline { 2 - 3 } & 2015 & Aktif \\
\hline
\end{tabular}

Sumber : arsipskpd.batam.go.id, 2017

Berdasarkan dari data tersebut menunjukkan bahwa website Kecamatan Batam Kota pernah aktif terakhir ditahun 2015 lewat website www.skpd.batamkota.go.id namun pada perkembangan di website www.kecbatamkota.batam.go.id belum efektif dan kurang aktif padahal letak Kecamatan Batam Kota sendiri di tengah-tengah Kota Batam dan memiliki jumlah penduduk yang cukup padat sebagai berikut:

Berdasarkan data tersebut seharusnya Kecamatan Batam Kota sadar akan pertumbuhan penduduk yang semakin meningkat dan dibutuhkannya sistem informasi pemerintahan seperti website yang aktif dan bermanfaat untuk mempermudah pelayanan kepada masyarakat perkotaan seperti masyarakat dilingkungan Kecamatan Batam Kota. Sebagai Kecamatan di tengah-tengah perkotaan, jika implementasi terhadap program EGovernment berjalan efektif, dapat menjadi contoh yang baik bagi Kecamatan-kecamatan yang lainnya yang ada di Kota Batam.

Peneliti ingin mengetahui dan menganalisis program website yang di kelola oleh Kecamatan Batam Kota dalam meningkatkan pelayanan publik dan untuk mengetahui dan 
menganalisis faktor pendukung dan penghambat program website di Kecamatan Batam Kota terhadap pelayanan publik.

\section{TINJAUAN PUSTAKA}

\section{Implementasi Kebijakan}

Implementasi kebijakan di pandang dalam pengertian yang luas, tahap dari proses kebijakan segera setelah penetapan undang-undang. Implementasi dipandang secara luas mempunyai makna pelaksanaan undang-undang dimana berbagai aktor, organisasi, prosedur, dan teknik bekerja bersama-sama untuk menjalankan kebijakan dalam upaya untuk meraih tujuan - tujuan kebijakan atau program-program terkait dengan undang-undang. (Winarno, 2007: 144)

\section{e-government}

e-government merupakan suatu mekanisme interaksi baru antara pemerintah dengan masyarakat dan kalangan lain yang berkepentingan, dengan melibatkan penggunaan teknologi informasi (terutama internet) dengan tujuan memperbaiki mutu (kualitas) pelayanan. e-government adalah penyelenggaraan kepemerintahan berbasiskan elektronik untuk meningkatkan kualitas layanan publik secara efisien, efektif, dan interaktif. Dimana pada intinya e-government adalah penggunaan teknologi informasi yang dapat meningkatkan hubungan antara pemerintah dan pihak-pihak lain (penduduk, pengusaha, maupun instansi lain). (Indrajit, 2002: 36)

\section{Pelayanan Publik}

Menurut AG. Subarsono dalam Agus Dwiyanto (2005: 141) pelayanan publik didefinisikan sebagai serangkaian aktivitas yang dilakukan oleh birokrasi publik untuk memenuhi kebutuhan warga pengguna. Pengguna yang dimaksud adalah warga negara yang membutuhkan pelayanan publik, seperti pembuatan akta kelahiran, pembuatan KTP, akta nikah, akta kematian, sertifikat. Dan lain sebagainya yang termasuk dalam pelayanan dalam masyarakat.

\section{METODELOGI}

Metode yang digunakan dalam penelitian ini adalah kualitatif dengan peneliti sebagai instrumen sebagai instrumen kunci, teknik pengumpulan data dilakukan secara trianggulasi 
(gabungan), analisis data bersifat induktif, dan hasil penelitian kualitatif lebih menekankan makna dari pada generalisasi (Sugiyono 2012: 1). Jenis penelitian yang digunakan adalah jenis deskriptif kualitatif yang mempelajari masalah-masalah yang ada serta tata cara kerja yang berlaku (Sugiyono 2012: 11). Tempat penelitian ini akan dilakukan di Kecamatan Batam Kota. Data yang digunakan berupa data primer dan sekunder. Data primer diperoleh dari wawancara mendalam dengan beberapa narasumber menggunakan teknik purposive sampling. Sedangkan data sekunder diperoleh dari berbagai dokumen pemerintah daerah yang dapat mendukung penelitian ini. Dalam menganalisis data dilakukan secara deskriptif kualitatif yakni data yang terkumpul akan dikategorisasi, kemudian dianalisis secara deskriptif hingga diperoleh kesimpulan.

\section{PEMBAHASAN}

Menurut Purwanto dan Sulistyastuti (2012: 21) implementasi adalah kegiatan untuk mendistribusikan keluaran kebijakan (to delivery policy output) yang dilakukan oleh para implementer kepada kelompok sasaran (target group) sebagai upaya untuk menwujudkan tujuan kebijakan. Tujuan kebijakan diharapkan akan muncul manakala policy output dapat diterima dam dimanfaatkan dengan baik oleh kelompok sasaran sehingga dalam jangka panjang hasil kebijakan akan mampu diwujudkan. Implementasi program e-government di Kecamatan Batam Kota sesuai dengan pendekatan yang di kemukakan dari Edward III tentang Implementasi kebijakan dengan melihat bagaimana suatu kondisi dan juga situasi untuk kesuksesan suatu kebijakan publik dan juga melihat hambatan-hambatan utama dari kesuksesan kebijakan publik, dengan empat indikator yang bisa berpengaruh terhadap suatu keberhasilan ataupun kegagalan implementasi kebijakan publik yang dilakukan yaitu Komunikasi (Communication), Sumber daya (Resources), Disposisi (Dispotition), dan Struktur birokrasi (Bureaucratic structure).

\section{Komunikasi}

Komunikasi adalah suatu proses penyampaian pesan dari komunikator kepada komunikan (audien). Komunikasi juga merupakan suatu proses penyampaian pesan dari perumus kebijakan kepada pelaksana kebijakan selaku implementornya. Suatu kebijakan seharusnya di komunikasikan dengan baik dan jelas, akurat, dan juga konsisten sehingga tidak adanya ketidak jelasan informasi dari pembuat kebijakan kepada para implementor. Jika 
ada ketidak jelasan dalam menyampaikan isi dari sebuah kebijakan akan menimbulkan perbedaan penafsiran ataupun perbedaan pemahaman dari isi kebijakannya tersebut bahkan bisa sampai bertentangan. Dalam hal ini komunikasi sudah di lakukan dari Dinas Komunikasi dan Informasi Kota Batam untuk ke-12 Kecamatan yang ada di kota batam dalam hal pengembangan e-government ataupun website pemerintahan.

Namun pada implementasinya, website Kecamatan Batam Kota sejauh ini belum juga menunjukkan bahwa website yang ada harus berguna dan bermanfaat bagi masyarakat, bukan hanya sekedar ada saja. Kecamatan Batam Kota sampai saat ini belum menampilkan data, informasi maupun update kegiatan-kegiatan yang ada ataupun yang sudah di lakukan oleh Kecamatan Batam Kota sebagai agenda kegiatan di websitenya. Sehingga dapat dinilai dari websitenya, pelayanan berbasis teknologi informasi dan komunikasi yang di lakukan oleh Kecamatan Batam Kota melalui websitenya tidak terdapat pelayanan yang memudahkan masyarakat di sekitar lingkungan Kecamatan Batam Kota. Website Kecamatan Batam Kota sebagai berikut:
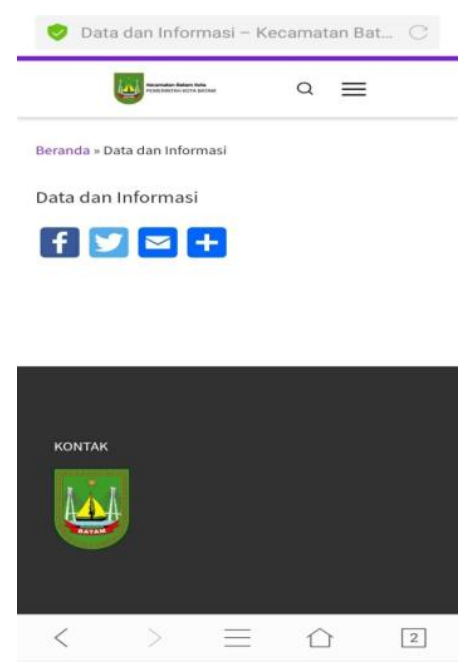

\section{Gambar 1. Website Kecamatan Batam Kota}

Sumber: https://kecbatamkota.batam.go.id, 2018

Dilihat dari gambar tersebut menunjukkan bahwa website Kecamatan Batam Kota masih belum memiliki informasi-informasi terkait sehingga tidak adanya sebuah pelayanan kepada masyarakat. Hal ini sangat di sayangkan oleh masyarakat di sekitar lingkungan Kecamatan yang membutuhkan informasi. Hal ini di perkuat juga dengan wawancara 
terhadap Bapak Ferianto Kasmadi selaku masyarakat di kelurahan sukajadi terkait dengan tujuan dan manfaat kebijakan mengenai website Kecamatan Batam Kota sebagai berikut:

\begin{abstract}
"Sangat berguna sekali jika website Kecamatan Batam Kota yang sudah ada dapat memberikan informasi-informasi yang berkaitan dengan pengurusan-pengurusan yang ada di Kecamatan Batam Kota maupun pengurusan di Kelurahan-kelurahannya. Jadi kita tidak perlu bertanya langsung, kita akses aja melalui internet tentang website Kecamatan Batam Kota”.
\end{abstract}

Dari pernyataan tersebut, dapat dikatakan bahwa komunikasi yang dilakukan oleh pemerintah yaitu Kecamatan Batam Kota belum tepat sasaran karna sasaran kebijakan dalam implementasi website ini adalah masyarakat di lingkungan Kecamatan Batam Kota yang akan mengurus kepentingannya masing-masing.

\title{
Sumber daya
}

Menurut Edward III sumber daya (Resources) memiliki peranan yang sangat penting dalam keberhasilan suatu implementasi kebijakan. Selanjutnya Edward III mengatakan bahwa jika para pelaksana (Implementor) kekurangan sumber-sumber yang di perlukan ataupun dibutuhkan dalam menjalankan kebijakan, maka implementasi tersebut tidak menjadi efektif, walaupun perintah Implementasi sudah di komunikasikan dengan akurat, jelas, serta konsisten. Aparatur ataupun ketersediaan sumber daya manusia (SDM) yang ada di Kecamatan Batam Kota merupakan hal yang paling penting dalam proses implementasi suatu kebijakan. Dalam hal ini sumber daya yang ada di Kecamatan Batam Kota sudah cukup memadai namun belum sesuai dengan bidang keahliannya. Hal ini di perkuat dengan wawancara terhadap Bapak M. Fairus R. Batubara, S.STP, M.Si selaku Camat Batam Kota terkait dengan sumber daya yang ada sebagai berikut:

"Untuk Sumber Daya, di Kecamatan Batam Kota ini Sumber Daya Manusianya masih kurang dimana sumber daya ini menurut saya memang harus sesuai dengan bidangnya harus sesuai dengan keahliannya sehingga pasti dapat mengimplementasikan program website di Kecamatan Batam Kota ini semakin baik lagi. sejauh ini untuk staf pengelola dan penanggung jawab website tersebut belum ada jadi dari kami Kecamatan untuk benar-benar memperhatikan dan menghidupkan website tersebut sangatlah kurang."

Ketersediaan Anggaran juga merupakan salah satu penunjang ataupun pendorong keberhasilan dalam implementasi suatu kebijakan. Jika anggaran kurang maka kebijakan itu tidak akan berjalan efektif. Pada hal ini anggaran merupakan tanggung jawab Dinas 
Komunikasi dan Informatika Kota Batam sebagai pembuat websitenya, Kecamatan Batam Kota hanya sebagai implementor berjalannya website tersebut. Ketersediaan Fasilitas Kebijakan juga merupakan termasuk salah satu sumber paling penting karena sebagai suatu fasilitas atau sarana prasarana dari kebijakan implementasi e-government Kecamatan Batam Kota tersebut. Di Kecamatan Batam Kota, fasilitas penunjang ataupun pendukung mengenai kebijakan e-goverment Kecamatan Batam Kota seperti komputer sudah ada dan tersedia di berbagai bidang sebagai berikut:

\section{Tabel 3 Data Jumlah Komputer Di Kecamatan Batam Kota}

\begin{tabular}{|c|c|c|}
\hline No. & Bidang & Jumlah Komputer \\
\hline 1. & Kasubbag Umum dan Kepegawaian & 2 \\
\hline 2. & Kasubbag Evaluasi Perencanaan dan Keuangan & 7 \\
\hline 3. & Kasi Pemerintahan & 2 \\
\hline 4. & Kasi Kesejahteraan Masyarakat & 2 \\
\hline 5. & Kasi Pembangunan dan Pemberdayaan Masyarakat & 2 \\
\hline 6. & Kasi Ketentraman dan Ketertiban & 2 \\
\hline 7. & Kasi Pelayanan Umum & 8 \\
\hline & Total & 25 \\
\hline
\end{tabular}

Sumber: Kesubbag Umum dan Kepegawaian Kecamatan Batam Kota

Dari data tersebut, seharusnya Kecamatan Batam Kota bisa meluangkan waktunya dalam mengontrol ataupun mengupdate websitenya agar dapat berjalan dengan baik sehingga masyarakat juga percaya pada website yang mereka lihat karna waktu dan tanggal yang di tampilkan menandakan bahwa website terebut memang berjalan sehingga informasiinformasi yang terdapat di dalamnya berupa informasi yang akurat.

\section{Disposisi}

Menurut Edward III disposisi merupakan suatu faktor yang memiliki konsekuensi penting bagi implementasi kebijakan yang efektif. Jika implementornya mempunyai sikap yang positif atau adanya dukungan terhadap implementasi kebijakan maka kemungkinan besar implementasi kebijakan akan bisa terlaksana sesuai dengan kesepakatan dan kesepahaman. Demikian sebaliknya, jika para pelaksana bersikap negatif atau menolak dan menghindar terhadap implementasi kebijakan akan menghadapi kendala.

Di Kecamatan Batam Kota budaya kerja yang dilakukan oleh aparat sudah sangat baik, bekerja sama merupakan suatu pola perilaku yang sudah melekat secara keseluruhan pada kepribadian setiap individu di Kecamatan Batam Kota. Dalam penerapan websitenya aparat 
Kecamatan Batam Kota saling bergantian ataupun berpindah tangan dalam mengelola maupun mengontrol websitenya karna memang di sana penanggung jawab websitenya belum pasti dan karna ketidak pastian itu menimbulkan ketidak maksimalan dalam pengelolaannya. Sifat Demokratis yang di Kecamatan Batam Kota juga sudah baik namun karna banyaknya kegiatan, acara, aupun tugas pokok Kecamatan menjadikan Kecamatan Batam Kota kurang fokus dalam mengimplementasikan websitenya dengan efektif kemasyarakat. Hal ini diperkuat dengan wawancara terhadap Bapak M. Fairus R. Batubara, S.STP, M.Si selaku Camat Batam Kota terkait dengan sifat demokratis aparat di Kecamatan Batam Kota terhadap implementasi program website di Kecamatan Batam Kota sebagai berikut:

"Disini kita bekerja secara gotong-royong dalam artian pekerjaan kita disini itu tidak stabil selalu berubah, agenda kegiatan Kecamatan cukup banyak, untuk membuat acara STQ dan Musrenbang semua pegawai disini harus ikut turun tangan untuk melaksanakan acara tersebut, tidak mungkin hanya 2 ataupun 3 orang saja, belum lagi kegiatan, acara, tugas Kecamatan Batam Kota yang lainnya, jadi kita juga kurang fokus dengan pengembangan dan mengelola website di Kecamatan Batam Kota ini."

Kemudian jika berbicara tentang insentif mengenai implementasi website ini di Kecamatan Batam Kota belum ada karna tugas Kecamatan hanya mengaktifkan dan memasukkan informasi-informasi mengenai Kecamatannya saja.

\section{Struktur birokrasi}

Struktur birokrasi adalah pembagian tugas dan tanggung jawab kepada masingmasing aparatur Kecamatan Batam Kota yang terlibat dalam implementasi program website di Kecamatan Batam Kota. Struktur birokrasi menjelaskan bagaimana kedudukan, tugas, dan fungsi yang di alokasikan kepada setiap pegawai yang terlibat di Kecamatan Batam Kota.

Fragmentasi atau penyebaran tanggung jawab yang terjadi di dalam Kecamatan Batam Kota akan terwujud melalui pola kinerja mereka yang saling bekerja sama untuk mensukseskan pelaksanaan implementasi kebijakan ini. Namun seperti yang terlihat pada saat ini bahwa penanggung jawab bukan satu orang saja melainkan keseluruhan Kecamatan Batam Kota dan tidak ada kesenjangan ataupun pilih kasih terhadap salah satu aparat. Hal ini diperkuat dengan wawancara terhadap Bapak M. Fairus R. Batubara, S.STP, M.Si selaku Camat Batam Kota terkait dengan fragmentasi atau penyebaran tanggung jawab yang terjadi didalam Kecamatan batam Kota yang berkaitan dengan implementasi program website di Kecamatan Batam Kota sebagai berikut: 
"Jadi tanggung jawab pelaksanaan program website ini di serahkan oleh Dinas Komunikasi dan Informatika ke kami Kecamatan Batam Kota. Tanggung jawab ini diberikan atau diinstruksikan oleh Pemerintah Kota Batam sesuai tupoksi mengenai EGovernment ataupun website Pemerintahan di Kota Batam. Dalam hal ini penyebaran tanggung jawab di Kecamatan Batam Kota dilakukan secara merata tidak ada kesenjangan-kesenjangan atau pilih kasih kepada para aparatur pelaksana."

Berdasarkan hasil wawancara tersebut, walaupun tanggung jawab yang dilimpahkan menyeluruh kepada Kecamatan Batam Kota tetap saja dilihat dari implementasi websitenya belum dijalankan secara maksimal. Kemudian juga dari segi standar operasional prosedur yang merupakan salah satu aspek penting sebagai pedoman tertulis yang di gunakan untuk tata cara atau tahapan-tahapan yang harus dilalui dalam implementasi website tersebut sudah ada namun pelaksanaannya juga masih kurang menyebabkan website terbengkalai.

\section{KESIMPULAN}

Berdasarkan hasil penelitian yang telah di bahas maka dapat di simpulkan bahwa di Kecamatan Batam Kota belum memanfaatkan secara optimal website pemerintahan yang sudah ada sebagai media pendukung penyelenggaraan pemerintahan yang bersih dan transparan. Faktor yang mempengaruhi E-Government pemerintah Kecamatan Batam Kota yang kurang aktif dapat dilihat dari indikator sebagai berikut:

\section{Komunikasi}

Kecamatan Batam Kota masih belum menunjukkan bahwa website tersebut merupakan kebijakan yang harus di laksanakan dan diutamakan mengingat website Kecamatan Batam Kota yang sudah ada namun belum beroperasi dengan baik dalam melayani masyarakat.

2. Sumber Daya

Sumber Daya Manusia (SDM) yang ada sudah cukup memadai namun belum sesuai dengan bidangnya ataupun kebutuhan untuk mengimplementasikan website tersebut.

3. Disposisi

Dalam mengimplementasikan website tersebut belum adanya aparat penanggung jawab ataupun adminnya sehingga dalam pengelolaan website dilakukan bergantian namun website belum berjalan dengan maksimal.

4. Struktur Birokrasi 
Standar Operasional Prosedur (SOP) Kecamatan Batam Kota yang sudah ada namun belum dilaksanakan menjadikan website tersebut belum terdapat informasi-informasi mengenai Kecamatan Batam Kota.

Berdasarkan dari ke empat indikator diatas, teknologi informasi dan komunikasi seperti website pemerintah Kecamatan Batam Kota yang sudah ada seharusnya dapat dimanfaatkan dengan baik dan benar. Karena e-government bertujuan untuk meningkatkan pelayanan publik. Berdasarkan kesimpulan yang telah di kemukakan sebagai berikut :

1. Meningkatkan pengawasan ataupun pemantauan berkala serta sanksi yang jelas kepada setiap Organisasi Perangkat Daerah (OPD) selaku implementor khususnya Kecamatan Batam Kota untuk meningkatkan websitenya agar berguna bagi masyarakat.

2. Mengadakan training/pelatihan yang layak untuk pengelolaan website di Kecamatan Batam Kota dalam rangka peningkatan kualitas pelayanan publik berbasis e-government.

3. Memberikan sosialisasi tentang website pemerintah khususnya Kecamatan Batam Kota yang dapat diakses dengan mudah melalui website di www.kecbatamkota.batam.go.id.

\section{DAFTAR PUSTAKA}

Dwiyanto, Agus. (2005). Mewujudkan Good Governance Melalui Pelayanan Publik. Yogyakarta: Gajah Mada University Press

Indrajit, Richardus Eko. (2002). Electronic Government: Strategi Pembangunan dan Pengembangan Sistem Pelayanan Publik Berbasis Teknologi Digital. Yogyakarta: Andi

Kumorotomo, Wahyudi. 2008. Pengembangan e-government Untuk Peningkatan Transparansi Pelayanan Publik Studi Kasus UPIK di Pemkot Jogjakarta dan EProcurement di Pemkot Surabaya. Diunduh dari https://s.id/j4uJa tanggal 6 Juni 2018

Purwanto, Erwan Agus dan Sulistyastuti, Dyah Ratih. 2012. Implemetasi Kebijakan Publik, Konsep, dan Aplikasinya di Indonesia. Yogyakarta: Gava Media.

Sugiyono, (2012). Metode Penelitian Kuantitatif, Kualitatif dan $R \& D$, Bandung: Alfabeta. Winarno, Budi. (2007). Kebijakan Publik, Teori, dan Proses. Jakarta: Media Pressindo. 